\section{Pavlychenko A. Adamchuk A., Shustov 0., Anisimov 0.}

\title{
JUSTIFICATION OF DUMP PARAMETERS IN CONDITIONS OF HIGH WATER SATURATION OF SOILS
}

The object of research is the stability parameters of the massif of a single-tier dump of soft overburden rocks with a flooded slope when it is formed by a dragline excavator. One of the most problematic areas is determining the safe distance of the dragline excavator from the upper edge of the slope in the conditions of the formation of a single-tier dump of soft overburden rocks, flooded with water.

The calculation of the width of the prism of possible shift was carried out using the Rocscience Slide software, which, taking into account the parameters of the slope and the physical and mechanical properties of the rock mass, automatically restores a number of curved sliding surfaces for individual safety factors. The obtained data were processed using the Microsoft Excel software, thanks to which, by the least squares method, graphs of the functions of the possible shift prism width from the height of the tier of a dump of soft overburden rocks and the level of its flooding were constructed.

For the conditions of the formation of a single-tier dump of soft rocks of overburden with a height of 40-100 m and a flooding level of $0-30 \mathrm{~m}$, the width of the prism of a possible shift was calculated for sliding surfaces with a safety factor of 1 and 1.2. These values are, respectively, 0-85.9 $\mathrm{m}$ and $0-122.6 \mathrm{~m}$ within the established calculation limits and depending on the method of constructing curved surfaces. The distance between the points of intersection of the horizontal surface of the tier with curved sliding surfaces with a safety factor of 1 and 1.2 is $16-52.5 \mathrm{~m}$. The dependences of the width of the prism of possible shift (a) on the height of the tier of a dump of soft overburden rocks $\left(H_{o}\right)$ and its level flooding $\left(H_{w}\right)$, taking into account the physical and mechanical properties of the dumped mountain range, including saturated with water. The minimum deviation from the initial value of the coordinates of the points is achieved when setting the second-degree polynomial as the trend line for the function $a=f\left(H_{w}\right)$, and for $a=f\left(H_{o}\right)-$ a straight line.

The obtained data for calculating the parameters of the possible shift prism suggest the possibility of forming a single-tier dump of soft overburden rocks with a height of 40-60 m with unloading of rock mass into the workedout space and 70-100 $\mathrm{m}$ with loading the unstable part of the slope with an EK-11/70 excavator-dragline (Novokramatorsk Machine-Building plant, Ukraine).

Keywords: dump of soft overburden rocks, possible shift prism, physical and mechanical properties, Rocscience Slide, safety factor.

Received date: 10.08 .2020

Accepted date: 17.09 .2020

Published date: 31.12 .2020
Copyright (C) 2020, Pavlychenko A., Adamchuk A., Shustov O., Anisimov O. This is an open access article under the CC BY license (http://creativecommons.org/licenses/by/4.0)

\section{Introduction}

Dumping is an important and integral process of opencast mining of mineral deposits. Depending on the conditions of the deposit, the dumping technology changes. So, the development of steeply dipping deposits is accompanied by the formation of external dumps of overburden rocks, which are located, as a rule, near quarries or at a distance of more than $5 \mathrm{~km}$ from them [1]. Whereas, during the development of shallow deposits, it is possible to form a dump of soft overburden rocks directly in the worked out intra-pit space during the advancement of the mining front [2]

The formation of an internal dump of soft overburden rocks is possible with the use of non-transport, transportdump, transport and combined field development systems. The development of the field by a non-transport system is limited by the height of the opening ledge up to $40-45 \mathrm{~m}$, depending on the dump management scheme [3]. The transport-dump system provides for the construction of a spreader and/or a transport-dump bridge, associated with the need for significant capital investments. With the transport system of development, the movement of overburden rocks into the worked-out space is carried out by conveyor, rail or road transport, as well as their combinations. For dumping during the transportation of overburden rocks, spreaders are used with conveyors, and for railway and road transport - shovel excavators, or dragline excavators.

The use of a transport system, in particular dump trucks in combination with shovel excavators and dragline excavators, is associated with high current costs, but lower capital costs. In addition, the characteristic features of the transport system are the presence of transport communications, the possibility of intensifying the preparation for the extraction of mineral reserves, the dispersal of mining operations and the independence of stripping operations from the mining operations [3]. 
For example, the thickness of overburden rocks in Ukrainian open-pit mines, developed gentle deposits, is on average:

- Nikopol manganese ore basin - 55.7 m [4];

- Dnipro brown coal basin - 53.7 m [5] (in particular, Morozivka brown coal mine - $83 \mathrm{~m}$, Kostiantynivka $78.5 \mathrm{~m}$ );

- Ciscarpathian sulfur-bearing basin - 70-75 m (in the northern part of the Rozdil deposit - $50.7 \mathrm{~m}$ ) [6, 7].

Therefore, the reconstruction can only be associated with a combined or transport systems for the development of a hollow field. The overwhelming majority of open-pit mines with a shallow bedding of mineral resources have ceased to be exploited. The workings formed by open pit mining were filled with water. Reconstruction of these quarries is associated with the need for a large amount of investment, which in the long term may not pay off. Therefore, at present, the trend in scientific and practical developments should be the minimization of capital investments, including by reducing the number of mining equipment involved.

According to the author of [8], soft overburden rocks are characterized by large intergranular voids, unstable structure and high susceptibility to external factors, in particular, to changes in water content. The studies carried out made it possible to assess the effect of water content on the change in stability parameters and the nature of the stress-strain state of the dump massif. An increase in water content promotes plastic deformation of the dump mass and, at relatively low loads, the intergranular voids are tightened, the porosity is greatly reduced, and the compaction increases.

Dump design and planning are essential elements of effective mine planning, especially in large scale open pits [9]. Capital and transportation costs for infrastructure are significant initially in the mining project and throughout the life of the quarry, as these dumps gradually develop into huge structures. The rates of production are determined, as well as certain spatial and physical constraints provide a set of parameters for the mathematical and economic relationship, creates opportunities for modeling and thereby facilitates the measurement and optimization of the final design of the dump using programmatic and empirical methods when achieving economic goals.

The solution to these problems is possible by controlling the blade height. Therefore, in order to reduce the park of mining equipment for the formation of internal dumps, it is necessary to have knowledge about the change in the width of the prism of a possible shift depending on the height of the dump and the level of its flooding.

Thus, the object of research is the stability parameters of the massif of a single-tier dump of soft overburden rocks with a flooded slope when it was formed by a dragline excavator. And the aim of research is to calculate the width of the prism of a possible shift when a single-tier dump of overburden with a flooded slope is formed by a dragline excavator, taking into account the physical and mechanical properties of rocks. Including, in conditions of their high water saturation, as well as the height of the dump tier and the level of its flooding with water.

\section{Methods of research}

Based on the above data, to build a model of the slope of the tier of the inner dump of soft rocks, let's take its height $40-100 \mathrm{~m}$ with a step of $10 \mathrm{~m}$, and the level of its flooding is $0-30 \mathrm{~m}$. It makes no sense to consider a higher flooding level, since at a depth more than $20-30 \mathrm{~m}$ it is impossible to develop a hollow deposit.

In soft rocks of overburden, special molecular and watercolloidal bonds are present, which act when particles approach up to $0.004 \mathrm{~mm}$. Under their influence, a layer of molecularly bound water several molecules thick is pressed against the lobe. Next a layer of loosely bound water comes, which envelops each lobe, and then free steam water [8]. Therefore, the physical and mechanical properties of the rock mass of the overburden, namely the angle of internal friction $(\rho, \operatorname{deg})$ and adhesion $(K, \mathrm{kPa})$ depend on the moisture content ( $W, \%)$ (Fig. 1).
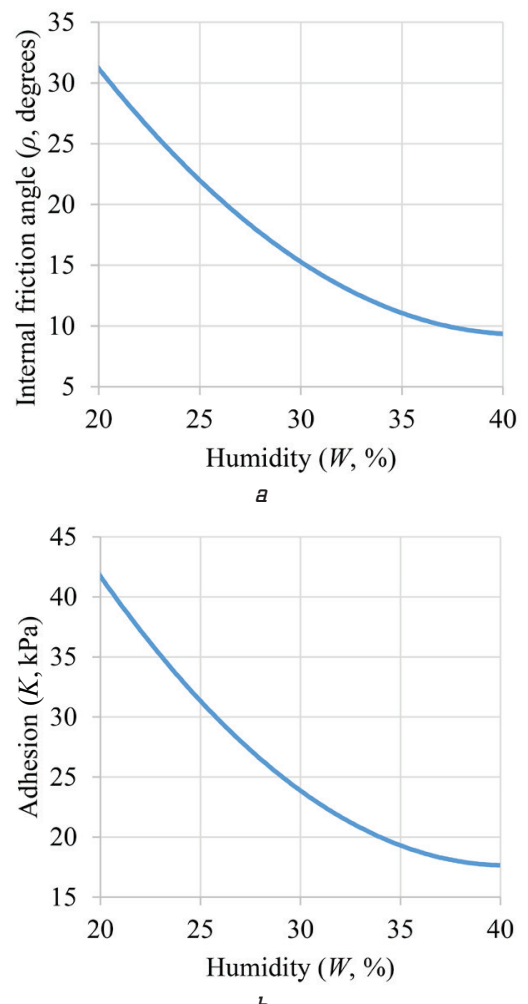

Fig. 1. Dependence: $a$ - angle of internal friction $\rho$, deg; $b$ - adhesion $K n, \mathrm{kPa}$, on the moisture content of soft rocks $W, \%$ [10]

The empirical dependences of the angle of internal friction $(\rho$, deg $)$ and cohesion $(K, \mathrm{kPa})$ on the moisture content of soft rocks $(W, \%)$ are as follows:

$$
\begin{aligned}
& \rho=0.05 W^{2}-4.1 W+93, \\
& K=0.058 W^{2}-4.7 W+112.3 .
\end{aligned}
$$

Thus, taking into account the previous experience of such calculations, let's accept the following physical and mechanical properties of the mass of soft overburden rocks: volumetric weight $-20.6 \mathrm{kN} / \mathrm{m}^{3}$, adhesion $-44 \mathrm{kPa}$, angle of internal friction $-21^{\circ}$. Rocks dumped in the dump in the underwater part: volumetric weight $-20.0 \mathrm{kN} / \mathrm{m}^{3}$, adhesion $-22 \mathrm{kPa}$, angle of internal friction $-18^{\circ}$ [11]. The slope angle of the soft rock massif is assumed to be $35^{\circ}$ [12].

\section{Research results and discussion}

The calculation of the width of the prism of possible shift is carried out using the Rocscience Slide software (Fig. 2). 


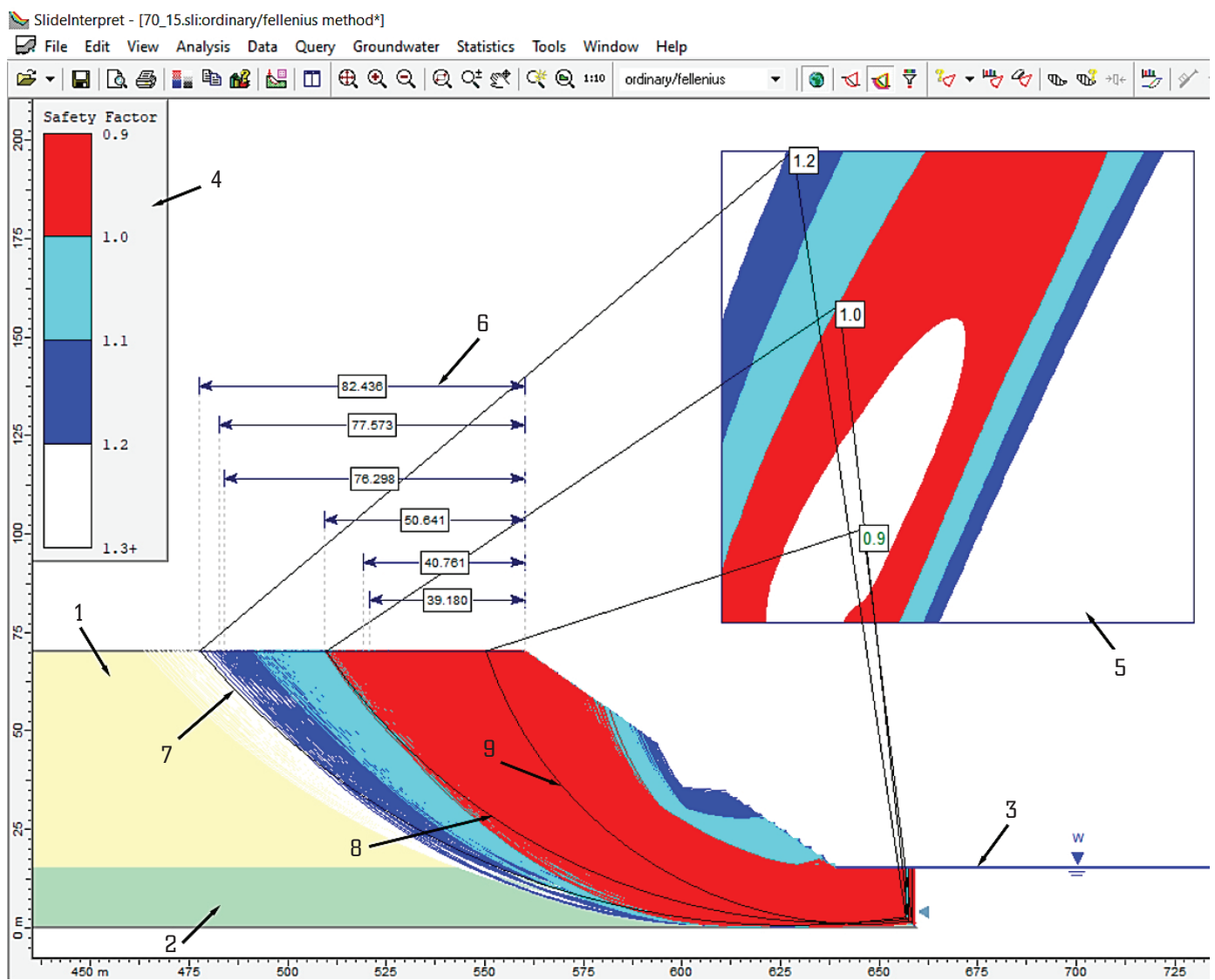

Fig. 2. An example of calculating the width of the prism of a possible shift of the slope of a dump of soft rocks of overburden with a height of $70 \mathrm{~m}$, a flooding level of $15 \mathrm{~m}$ in the Slide program: 1 - non-watered part of the slope; 2 - watered part of the slope; 3 - flooding level; 4 - legend, which reflects the limits of the safety factor values; 5 - square in which the centers of the radii of curved sliding surfaces are located; 6 - dimension lines of the width of the prism of a possible shift; 7 - sliding surface with a safety factor $K_{y}=1.2 ; 8$ - sliding surface with a safety factor $K_{y}=1$; 9 - sliding surface with the smallest safety factor

The essence of the Slide program is that:

- section of the calculated array is restored;

- data on physical and mechanical properties of rocks are entered;

- position of the square is determined, in which the centers of the radii of the curved sliding surfaces are located, along which the program calculates the safety factors in accordance with all points of the centers and radii and indicates the smallest indicator. Next, a sliding surface with the required safety factor is selected, which is located further from the slope of the tier. Then the width of the prism of possible shift is determined (the distance between the point of intersection of the selected sliding surface and the upper edge of the slope of the tier). The data obtained are entered in Table 1.

The value of the possible shift prism width $a_{1,2}$ at $K_{y}=1.2$ is calculated to be able to determine the distance of the dragline excavator from the upper edge of the slope of the tier of a dump of soft rocks, in accordance with the regulatory requirements for the safety of mining equipment.

On a part of the slope of the slope of the dump of soft rocks of overburden with a safety factor less than $K_{y}=1$, deformation of the rock mass occurs. Calculation of the width of the prism of a possible shift for curved surfaces with a safety factor $K_{y}=1$ will justify the expediency of using dragline excavators when forming a single-tier dump of soft overburden rocks in a controlled deformation mode [13].

Based on the obtained data for calculating the width of the prism of a possible shift in the Excel program, let's create separately for each value of the height of the slope of a single-tier dump, arrays of points, the abscissas of which are the level of flooding of the slope with water, and the ordinates are the width of the prism of a possible shift. A trend line is drawn through the created points, which is built using the least squares method in automatic mode. For the obtained trend line, let's obtain the equation of the function describing the desired dependence of the width of the prism of a possible shift on the height of the dump tier and the level of its flooding (Fig. 3).

The obtained functions $a_{1,2}=f\left(H_{w}\right)$ and $a_{1}=f\left(H_{w}\right)$ within the established limits have a quadratic dependence, and $a_{1,2}=f\left(H_{0}\right)$ and $a_{1}=f\left(H_{o}\right)$ - linear with the approximation confidence value close to 1 . Moreover, with an increase in the height of the dump layer, the width of the prism of a possible shift increases, and with an increase in the level of flooding of the slope, it first increases, and after reaching the value $H_{w}=0.2-0.3 H_{o}$ it decreases.

The distance between the points of intersection of the horizontal surface of the tier with curved sliding surfaces with a safety factor of 1 and 1.2 is $16-52.5 \mathrm{~m}$. Moreover, this value for a slope not flooded with water is 16-48.2 m, and if to exclude the values, where $a_{1}=0 \mathrm{~m}$, then $32.7-39.4 \mathrm{~m}$. 
Results of calculating the width of the prism of possible shift in the Slide program

\begin{tabular}{|c|c|c|c|c|c|c|c|c|}
\hline \multirow{3}{*}{$\begin{array}{l}\text { No. of } \\
\text { model }\end{array}$} & \multirow{3}{*}{$\begin{array}{l}\text { Tier height, } \\
\quad H_{0,} \mathrm{~m}\end{array}$} & \multirow{3}{*}{$\begin{array}{c}\text { Flooding } \\
\text { level, } H_{W,} \mathrm{~m}\end{array}$} & \multicolumn{6}{|c|}{ Possible shift prism width } \\
\hline & & & \multicolumn{3}{|c|}{ At $K_{Y}=1-a_{1}, \mathrm{~m}$} & \multicolumn{3}{|c|}{ At $K_{Y}=1.2-a_{1,2}, \mathrm{~m}$} \\
\hline & & & Bishop method & Fellenius method & Spencer method & Bishop method & Fellenius method & Spencer method \\
\hline 1 & 40 & 0 & 0 & 0 & 0 & 16 & 22.3 & 16.2 \\
\hline 2 & 40 & 5 & 0 & 0 & 0 & 30.2 & 35 & 30.2 \\
\hline 3 & 40 & 10 & 0 & 0 & 0 & 31.4 & 36.8 & 31 \\
\hline 4 & 40 & 15 & 0 & 0 & 0 & 20.7 & 30.5 & 23.3 \\
\hline 5 & 40 & 20 & 0 & 0 & 0 & 0 & 18.8 & 0 \\
\hline 6 & 40 & 25 & 0 & 0 & 0 & 0 & 0 & 0 \\
\hline 7 & 40 & 30 & 0 & 0 & 0 & 0 & 0 & 0 \\
\hline 8 & 50 & 0 & 0 & 0 & 0 & 34.1 & 38.8 & 33.2 \\
\hline 9 & 50 & 5 & 8.6 & 23.2 & 12.9 & 45.1 & 50.1 & 45 \\
\hline 10 & 50 & 10 & 10.5 & 26.7 & 12.4 & 45.7 & 52.6 & 47.7 \\
\hline 11 & 50 & 15 & 10.7 & 23 & 10.4 & 44.9 & 51.5 & 45.3 \\
\hline 12 & 50 & 20 & 0 & 0 & 0 & 37.5 & 46.4 & 37.7 \\
\hline 13 & 50 & 25 & 0 & 0 & 0 & 23 & 35.4 & 23.9 \\
\hline 14 & 50 & 30 & 0 & 0 & 0 & 0 & 0 & 0 \\
\hline 15 & 60 & 0 & 0 & 21.6 & 0 & 48.2 & 53.5 & 48.2 \\
\hline 16 & 60 & 5 & 25.4 & 36.3 & 26.6 & 58.2 & 64.2 & 58.8 \\
\hline 17 & 60 & 10 & 28.3 & 39.2 & 29.2 & 61.8 & 68.2 & 62.5 \\
\hline 18 & 60 & 15 & 25.6 & 37.9 & 26.6 & 61.4 & 68.4 & 61.4 \\
\hline 19 & 60 & 20 & 10.5 & 31.9 & 15.5 & 57.8 & 65.5 & 57.8 \\
\hline 20 & 60 & 25 & 0 & 22.8 & 0 & 50 & 59.5 & 50.8 \\
\hline 21 & 60 & 30 & 0 & 10.3 & 0 & 37.3 & 49.5 & 37.7 \\
\hline 22 & 70 & 0 & 25.5 & 34.8 & 25.2 & 61.1 & 67.5 & 61.1 \\
\hline 23 & 70 & 5 & 36.1 & 45.9 & 37.5 & 72.1 & 79.8 & 72.1 \\
\hline 24 & 70 & 10 & 40.7 & 50.6 & 40.8 & 76.2 & 82.4 & 76.3 \\
\hline 25 & 70 & 15 & 39.2 & 50.7 & 40.7 & 76.3 & 82.4 & 77.6 \\
\hline 26 & 70 & 20 & 34.8 & 47.5 & 36.1 & 74.1 & 82.4 & 75.5 \\
\hline 27 & 70 & 25 & 25.8 & 42.5 & 27.3 & 69.5 & 79.8 & 69.5 \\
\hline 28 & 70 & 30 & 9.9 & 32.8 & 13.8 & 62.4 & 72.9 & 62.4 \\
\hline 29 & 80 & 0 & 38.6 & 46.5 & 40 & 74.9 & 80.9 & 74.1 \\
\hline 30 & 80 & 5 & 46.5 & 56.1 & 46.5 & 85.6 & 94.1 & 85.6 \\
\hline 31 & 80 & 10 & 50.3 & 61.8 & 51.8 & 90.2 & 94.2 & 90.2 \\
\hline 32 & 80 & 15 & 52 & 61.8 & 53.4 & 91.1 & 94.1 & 91.1 \\
\hline 33 & 80 & 20 & 49.9 & 61.8 & 51.3 & 90.1 & 94.2 & 90.1 \\
\hline 34 & 80 & 25 & 43.6 & 57.9 & 44.8 & 87.3 & 94.1 & 87.3 \\
\hline 35 & 80 & 30 & 34.5 & 52 & 36 & 82.4 & 92.7 & 82.4 \\
\hline 36 & 90 & 0 & 50.3 & 57.9 & 50.3 & 86.8 & 95.4 & 86.8 \\
\hline 37 & 90 & 5 & 56.2 & 67.1 & 56.7 & 98.1 & 105.9 & 99.7 \\
\hline 38 & 90 & 10 & 61.5 & 71.5 & 62 & 102.6 & 105.9 & 104.2 \\
\hline 39 & 90 & 15 & 63.5 & 73.5 & 63.5 & 105.9 & 105.9 & 105.9 \\
\hline 40 & 90 & 20 & 62 & 73.7 & 63.8 & 106 & 107.3 & 106 \\
\hline 41 & 90 & 25 & 58.2 & 71.5 & 59.8 & 102.5 & 107.3 & 102.5 \\
\hline 42 & 90 & 30 & 51.1 & 67.1 & 52.6 & 98.1 & 106 & 99.8 \\
\hline 43 & 100 & 0 & 60 & 68.5 & 60 & 99.3 & 107.9 & 99.3 \\
\hline 44 & 100 & 5 & 66 & 77.2 & 66.7 & 112.1 & 117.7 & 112.8 \\
\hline 45 & 100 & 10 & 71.2 & 81.6 & 71.6 & 116 & 117.8 & 117.8 \\
\hline 46 & 100 & 15 & 74.1 & 85.3 & 74.5 & 117.6 & 118.3 & 117.6 \\
\hline 47 & 100 & 20 & 74.1 & 85.9 & 74.9 & 117.7 & 121 & 117.7 \\
\hline 48 & 100 & 25 & 72.2 & 84.6 & 72.9 & 117.6 & 122.6 & 117.6 \\
\hline 49 & 100 & 30 & 67.7 & 81.6 & 68.5 & 115.8 & 121 & 115.8 \\
\hline
\end{tabular}




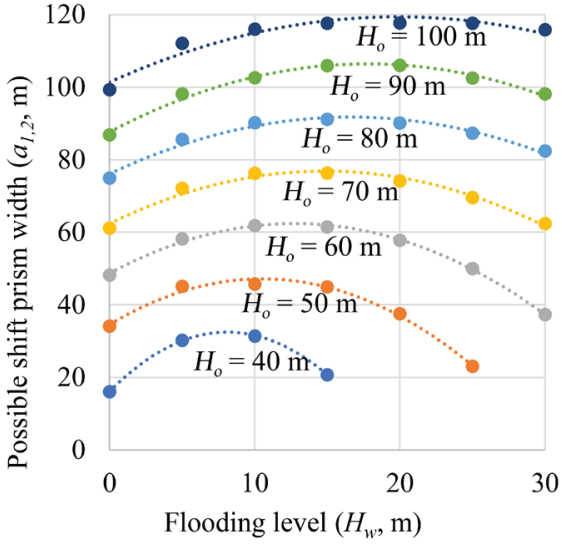

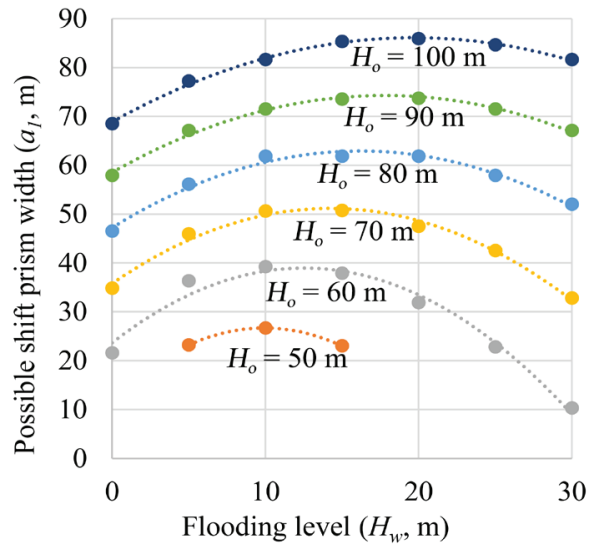

Fig. 3. Graphs of the dependence of the width of the prism of a possible shift on: $a$ - heights of the tier of a dump of soft rocks; $b$ - flooding level

\section{Conclusions}

The obtained data for calculating the parameters of the prism of a possible shift suggests the possibility of the formation of a single-tier dump of soft overburden rocks with a height of 40-60 m with unloading of rock mass into the worked-out space and 70-100 $\mathrm{m}$ with loading the unstable part of the slope with an EK-11/70 excavatordragline (Novokramatorsk Machine-Building plant, Ukraine).

The presence of sliding surfaces with a safety factor less than $K_{y}=1$ indicates the possibility of deformation processes of the slope from the side of the mined-out intrapit space. To substantiate the expediency of the formation of a single-tier high dump of soft overburden rocks with a dragline excavator, the following works should comprehensively investigate the nature of these deformations in connection with the technology of dumping in a controlled deformation mode.

\section{References}

1. Dryzhenko, A. Yu., Adamchuk, A. A., Tamuia, S. A., Telnov, V. H. (2018). Doslidzhennia parametriv vnutrishnikh vidvaliv u vyroblenomu prostori vidpratsovanykh hlybokykh karieriv. Zbirnyk Naukovykh Prats Natsionalnoho Hirnychoho Universytetu, 53, 56-65. Available at: http://nbuv.gov.ua/UJRN/ znpngu $201853 \quad 8$

2. Drizhenkko, A. Iu. (2011). Karernye tekhnologicheskie gornotransportnye sistemy. Dnepropetrovsk: NGU, 542.

3. Novozhilov, M. G., Khokhriakov, V. S., Pchelkin, G. D., Eskin, V. S.; Novozhilov, M. G. (Ed.) (1971). Tekhnologiia otkrytoi razrabotki mestorozhdenii poleznykh iskopaemykh. Chast 2. Tekhnologiia i kompleksnaia mekhanizatsiia otkrytykh razrabotok. Moscow: Nedra, 552.

4. Lozhnikov, A. V., Adamchuk, A. A. (2017). Issledovanie vliianiia ispolzovaniia krutonaklonnykh konveierov na effektivnost rekultivatsionnykh rabot pri razrabotke pologikh mestorozhdenii. Zbirnik Naukovikh Prats Natsionalnogo Girnichogo Universitetu, 51, 45-54. Available at: http://nbuv.gov.ua/UJRN/znpngu_2017_51_7

5. Surhai, M. S., Kulish, V. A. (2007). Perspektyvy vydobutku ta pererobky buroho vuhillia v Ukraini. Donetsk: Vydavnytstvo «Donbas», 60 .

6. Panas, R., Malanchuk, M. (2010). Tekhnolohiia formuvannia i rekultyvatsii vidvaliv rozkryvnykh porid na terytorii peredkarpatskoho sirkonosnoho baseinu. Suchasni Dosiahnennia Heodezychnoi Nauky ta Vyrobnytstva, 2, 176-182.
7. Haidin, A. M., Zozulia, I. I. (2011). Novyi Rozdil. Narodzhenyi sirkoiu. Istoriia, liudy, dovkillia. TDV «Instytut HIRKhIMPROM», 56.

8. Woźniak, H. (2009). Influence of water content on compressibility of cohesive dump soils - results of studies on samples of modeled lump size distribution. Geologija, 51 (1-2 (65-66)), 53-58. doi: http://doi.org/10.2478/v10056-009-0006-0

9. Puell Ortiz, J. (2017). Methodology for a dump design optimization in large-scale open pit mines. Cogent Engineering 4 (1). doi: http://doi.org/10.1080/23311916.2017.1387955

10. Arsentev, A. I., Bukin, I. Iu., Mironenko, V. A. (1982). Ustoichivost bortov $i$ osushenie karerov. Moscow: Nedra, 165.

11. Nikolashin, Iu. M. (2010). Otchet NIR: Zakliuchenie po obosnovaniiu uslovii bezopasnogo skladirovaniia vskryshnykh porod v otrabotannii karer GOKa. Otchet o NIR/NOVOTEK, 1/AR-10 (2433), 53.

12. Kopach, P. I., Krasnopolskii, I. A., Polischuk, S. Z., Shpar, A. G. (1988). Upravlenie sostoianiem massivov na otkrytykh razrabotkakh. Kyiv: Naukova dumka, 248.

13. Nikolashin, Iu. M., Kebal, Ia. V. (2016). Puti ispolzovaniia ploschadei ostatochnykh otkrytykh gornykh vyrabotok, zatoplennykh podzemnymi vodami. Visnik Krivorizkogo Natsionalnogo Universitetu, 43, 45-47. Available at: http://nbuv.gov.ua/UJRN/ Vktu_2016_43_12

Pavlychenko Artem, Doctor of Technical Sciences, Professor, Head of Department of Ecology and Technologies of Environmental Protection, National Technical University Dnipro Polytechnic, Dnipro, Ukraine,e-mail: pavlichenko.a.v@nmu.one,ORCID: http://orcid.org/ 0000-0003-4652-9180

Adamchuk Andrii, Senior Researcher, Department of Surface Mining, National Technical University Dnipro Polytechnic, Dnipro, Ukraine, e-mail: Adamchuk.A.A@nmu.one, ORCID: http://orcid.org/00000002-8143-3697

Shustov Oleksandr, PhD, Associate Professor, Department of Surface Mining, National Technical University Dnipro Polytechnic, Dnipro, Ukraine, e-mail: Shustov.O.O@nmu.one, ORCID: http:// orcid.org/0000-0002-2738-9891

Anisimov Oleh, PhD, Associate Professor, Department of Surface Mining, National Technical University Dnipro Polytechnic, Dnipro, Ukraine, e-mail: aoa76@ukr.net, ORCID: https://orcid.org/00000001-8286-7625 